\title{
Effect of Three Different Electrolyte Additives on Corrosion Resistance of Micro-arc Oxidation Coating of NiTi Alloy in Simulated Body Fluid
}

\author{
Yao Yao, Wenlan Cai, Zhenxia Wang ${ }^{*}$, Naiming Lin, Linhai Tian, Lin Qin, Yucheng Wu \\ Institute of New Carbon Materials, Taiyuan University of Technology, 030024 \\ "E-mail: wangzhenxia@tyut.edu.cn; wyc@tyut.edu.cn
}

doi: $10.20964 / 2020.12 .13$

Received: 6 July 2020 / Accepted: 7 September 2020 / Published: 31 October 2020

\begin{abstract}
In this paper, a micro-arc oxidation (MAO) coating was formed on $\mathrm{NiTi}$ alloy in a $0.2 \mathrm{~mol} / \mathrm{L} \mathrm{NaAlO}_{2}$ base electrolyte with three additives of $0.03 \mathrm{~mol} / \mathrm{L} \mathrm{NaOH}, 0.03 \mathrm{~mol} / \mathrm{L} \mathrm{NaH} \mathrm{PO}_{2}$ and $0.03 \mathrm{~mol} / \mathrm{L}$ $\mathrm{Na}_{3} \mathrm{PO}_{4}$, respectively. The influence of different additives on the surface morphology and corrosion resistance of the MAO coatings was systematically investigated. The result revealed that a relatively flat MAO ceramic coating with a typical MAO porous morphology was presented in the electrolyte with $\mathrm{NaH}_{2} \mathrm{PO}_{2}$. The coating showed the best corrosion resistance which was verified by the smallest corrosion current density after polarization test, indicating that $\mathrm{NaH}_{2} \mathrm{PO}_{2}$ was an ideal additive. On the base of the above results, $\mathrm{MAO}-\mathrm{NaH}_{2} \mathrm{PO}_{2}$ coating was mainly studied. The section morphology indicated that the MAO-NaH${ }_{2} \mathrm{PO}_{2}$ coating was composed of the dense inner layer and loose outer layer, with a thickness of $5.4 \mu \mathrm{m}$. XRD showed that the MAO- $\mathrm{NaH}_{2} \mathrm{PO}_{2}$ coating was mainly composed of $\mathrm{Al}_{2} \mathrm{O}_{3}$. It was also proved that the wear resistance of the $\mathrm{MAO}-\mathrm{NaH}_{2} \mathrm{PO}_{2}$ coating had been improved.
\end{abstract}

Keywords: NiTi alloy; micro-arc oxidation; corrosion resistance; wear resistance

\section{$\underline{\text { FULL TEXT }}$}

(C) 2020 The Authors. Published by ESG (www.electrochemsci.org). This article is an open access article distributed under the terms and conditions of the Creative Commons Attribution license (http://creativecommons.org/licenses/by/4.0/). 